\title{
Effect of Spraying Amino Acids and Micronutrients as Well as their Combination on Growth, Yield, Fruit Quality and Mineral Content of Canino Apricot Trees \\ El-Badawy, H. E. M. \\ Hort. Dept., Fac. Agric., Benha Univ., Egypt. (hamed.albadawy@fagr.bu.edu.eg).
}

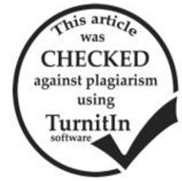

\begin{abstract}
This work was conducted during 2016 and 2017 seasons in a private orchard at El-Khatatba region, Minofia Governorate, Egypt to study the effect of some foliar application of amino acids at $0.0,1,2$ and $3 \mathrm{ml} / \mathrm{L}$ and micronutrients mixture i.e., $\mathrm{Fe}+\mathrm{Zn}+\mathrm{Mn}$ each at $0.0,50,100$ and $150 \mathrm{ppm}$ as well as their combination on growth, yield, quality and leaf mineral content of Canino apricot trees. The trees used in this experiment were eight-year-old planted at $4 \times 5 \mathrm{~m}$ apart and budded on local apricot rootstock, grown in a sandy soil under drip irrigation system and received the common cultural practices. The trees selected to be healthy and uniform in growth and yield as possible. The gained results showed that the longest shoots, the highest number of leaves/shoot and the largest leaf area were obtained from the combination of amino acids at the high rate $(3 \mathrm{ml} / \mathrm{L})$, particularly those sprayed with micronutrients at the high level $(150 \mathrm{ppm})$ in the two seasons. The highest fruit set \% was scored by the interaction of amino acids at the high rate, especially those received micronutrients foliar spray at the high level in the two seasons. The heaviest fruit and the highest yield/ fed. were noted by the combined treatment between amino acids at $3 \mathrm{ml} / \mathrm{L}$ and micronutrients at $150 \mathrm{ppm}$ in the two seasons. The highest values of fruit firmness obtained from the combination of micronutrients at the high level, particularly those received amino acids at the high rate $(3$ $\mathrm{ml} / \mathrm{L}$ ) in both seasons. $3 \mathrm{ml} / \mathrm{L}$ amino acids sprayed plus micronutrients at $150 \mathrm{ppm}$ induced the highest values of fruit T.S.S. \%, fruit total sugars \% and V.C (mg/ 100ml juice). The highest values of leaf N, P, K, Fe, Zn and Mn contents were obtained by using the mixed treatment between amino acids at $3 \mathrm{ml} / \mathrm{L}$ and micronutrients at $150 \mathrm{ppm}$ in both seasons. Conclusively, spraying Canino apricot trees with amino acids at $3 \mathrm{ml} / \mathrm{L}$ and received micronutrients at $150 \mathrm{ppm}$ foliar spray induced prospective effects on vegetative growth and fruits yield and quality.
\end{abstract}

Keywords: Canino apricot, amino acids, micronutrients, growth, yield, quality and chemical composition.

\section{INTRODUCTION}

Apricot (Prunus armeniaca L.) is one of the fruit tree species planted on a large scale over the world. Apricots have important nutritional properties; it is strongly recommended to consume them in cases of vitamin A and trace element deficiencies, anaemia, physical and mental fatigue, depression, neurosis, stress, etc. (Iordanescu, et al. 2012). Apricots are a tonic for the nervous system and improve the body's natural defence reaction. Hence, they have an alkaline action, apricots help maintain the acidbase balance in the blood and body tissues and reduce acidity resulting from a diet too rich in meat and flour products. Apricot fruits contain the major minerals $\mathrm{K}, \mathrm{Ca}$, and $\mathrm{Mg}$ (Drogoudi et al., 2008). Apricot fruit contains lycopene, which helps to prevent cancer and protects the body from high cholesterol, thus preventing heart disease.

Recently, some cultivars of apricot have been evaluated for their antioxidant activity, suggesting their health-promoting effects in the human diet (Leccese et al., 2010). Antioxidant compounds, such as carotenoids, polyphenols, and vitamin $\mathrm{C}$, have been evaluated in high amounts in apricot fruit (Caliskan et al., 2012 and Fratianni et al., 2018).

Amino acids are considered as precursors and constituents of proteins which are necessary for promoting cell growth. They contain both acid and basic groups and act as buffers, which led to maintain favourable $\mathrm{pH}$ value within the plant cell (Davies, 1982). Amino acids can directly or indirectly affect the physiological activities in plant growth and development. Exogenous application of amino acids have been reported to improve the growth, yield and biochemical quality of grapes (Khan et al., 2012), apples (Arabloo et al., 2017) and pears (Fayek et al., 2011).

The incidence of micronutrients deficiencies in fruit crops has increased markedly in the recent years due to intensive cropping, losses of micronutrients through leaching, decreased amounts of organic fertilizers application as compared to chemical fertilizers, increased purity of chemical fertilizers, soil erosion and use of marginal lands (with high $\mathrm{pH}$ and $\mathrm{EC}$ ) for crop production (Zia et al., 2006). The climate change by weather warming and drying might be another important reason for the disorders. Micronutrients play an important role in production and its deficiency reduce the productivity. Apricot plants, also shows micronutrients deficiency and could be responsible for lower yield and quality. Foliar feeding of nutrients to fruit plants has gained much importance in recent years which is quite economical and obviously an ideal way of evading the problems of nutrients availability and supplementing the fertilizers to the soil. Micronutrients such as Fe, Zn and Mn are not only essential but they are equally important like other macronutrients, in spite of their requirements in micro quantities. Micronutrients are key elements in plants growth and development. These elements play very important role in various enzymatic activities and synthesis. These micronutrients also help in the uptake of major nutrients and play a vital role in the plant metabolism process starting from cell wall development to respiration, photosynthesis, chlorophylls formation, enzyme activity, hormone synthesis, nitrogen fixation and reduction (Das, 2003). Fe plays a key role in several enzyme-systems, in which haeme or haemin is the prosthetic group (Khurshid et al., 2008). Zn is involved in the biosynthesis of Tryptophan, a precursor of naturally occurring auxin, indole acetic acid (IAA) (Swietlik, 2002). $\mathrm{Mn}$ is required in the process of photosynthesis (Mengel and Kirkby, 1987).

The objective of this experiment was to investigate the effect of some foliar application of micronutrients and amino acids as well as their combination on growth, yield, quality and leaf mineral content of Canino apricot trees. 


\section{MATERIALS AND METHODS}

This work was conducted during 2016 and 2017 seasons in a private orchard at El-Khatatba region, Minofia Governorate, Egypt. Eight-year-old 'Canino' apricot trees (planted at $4 \times 5 \mathrm{~m}$ a part and budded on local apricot rootstock), grown in a sandy soil under drip irrigation system and received the common cultural practices. Physical and chemical properties of the soil of the experimental region are presented in Table (1).

Table 1. Soil characteristics of Canino apricot trees at the start of the experiment.

\begin{tabular}{|c|c|c|c|c|c|}
\hline $\begin{array}{l}\text { Mechanical } \\
\text { analysis }\end{array}$ & Value & $\begin{array}{c}\text { Chemical } \\
\text { analysis }\end{array}$ & Value & $\begin{array}{l}\text { Anion and } \\
\text { Cation } \\
\text { (Meq/I) }\end{array}$ & Value \\
\hline Coarse sand $\%$ & 47.9 & $\mathrm{CaCO}_{3} \%$ & 1.92 & $\mathrm{Ca}^{++}$ & 1.75 \\
\hline Fine sand $\%$ & 37.1 & $\begin{array}{c}\text { Field } \\
\text { capacity } \%\end{array}$ & 13.9 & $\mathrm{Na}^{+}$ & 1.85 \\
\hline Silt $\%$ & 12.7 & $\mathrm{PH}$ & 7.81 & $\mathrm{Mg}^{+}$ & 0.83 \\
\hline Clay $\%$ & 2.3 & $\begin{array}{l}\text { Organic } \\
\text { matter\% } \%\end{array}$ & 0.29 & $\mathrm{~K}^{+}$ & 0.20 \\
\hline Soil texture & sandy & $\begin{array}{l}\mathrm{EC}(\mathrm{ds} / \mathrm{m}) \\
\text { Total N\% }\end{array}$ & $\begin{array}{l}0.46 \\
0.10\end{array}$ & $\begin{array}{c}\mathrm{CO}_{3}^{--} \\
\mathrm{HCO}_{3}^{-} \\
\mathrm{Cl}^{-} \\
\mathrm{SO}_{4}^{--}\end{array}$ & $\begin{array}{c}0.0 \\
2.37 \\
1.44 \\
0.82\end{array}$ \\
\hline
\end{tabular}

The trees used in this experiment were selected to be healthy and uniform in growth behaviour and yield as possible. The trees were trained and pruned uniformly to an open centre shape. The selected trees were subjected to the following treatments:

Amino acids treatments: Canino apricot trees were foliar sprayed with Bioflow (commercial compound containing $27.3 \%$ amino acids) at the rate of $0.0,1,2$ and $3 \mathrm{ml} / \mathrm{L}$ for each three times a year started from the first week of March with two weeks intervals.

Micronutrients treatments: Canino apricot trees were foliar sprayed with a mixture of iron, zinc and manganese sulphate each at 0.0,50,100 and 150ppm three times a year started from the first week of March with ten days intervals.

Tween twenty at $0.01 \%$ was applied as a wetting agent to all sprayed solutions including the control. The trees were sprayed with the previous solutions till runoff. The apricot trees received the recommended agricultural practices regularly followed in commercial orchards at this region.

\section{- Experiment layout}

The design of the experiment was factorial experiments in a complete randomize block design with 16 treatments (4 micronutrients concentrations $\mathrm{x} 4$ amino acids concentrations). Each treatment was replicated three times, with three trees for each replicate.

The response of Canino apricot trees to the studied treatments was evaluated through the following data measurements: Eight branches selected around every tree were chosen and labelled before spraying to estimate the different gained data in the two seasons.

\section{- Vegetative growth aspects}

Data were recorded on shoot length, number of leaves/ shoot and leaf area were measured using planimeter during August.

\section{- Fruit yield aspects}

Fruit set was calculated in relation to the total number of flowers and then the percentages were calculated as follow: Fruit set $(\%)=$ No. of developing fruitlets x 100 /Total No. of flowers. Fruits were collected at maturity stage late of June from each tree of various replicates to determine fruit weight (g) and yield (ton/fed).

\section{- Fruit physical aspects}

Twenty fruits from each tree under study were chosen for estimating the fruit firmness which determined as $\mathrm{lb} / \mathrm{inch}^{2}$ using the pressure tester of $5 / 16$ inch plunger.

\section{- Fruit chemical aspects}

Data of chemical aspects were recorded for total soluble solids in fruit juice using a hand refractometer. Moreover, fruit titratable acidity (malic acid g/ 100ml fruit juice) and ascorbic acid (V.C) content (ascorbic acid mg/ $100 \mathrm{ml}$ fruit juice) were scored according to A.O.A.C. (1995). Fruit total sugars (\%) of fresh weight were determined using the Nelson arsenomolybdate colorimetric method as described by Malik and Singh (1980).

\section{- Leaf mineral content}

Leaf mineral content were measured in mid-April of both seasons. Samples of 30 leaves/tree were taken at random from the previously tagged shoots of each tree. Leaf samples were washed with tap water and distilled water twice, dried at $70{ }^{\circ} \mathrm{C}$ to a constant weight and then ground. The ground samples were digested with sulphuric acid and hydrogen peroxide. Total nitrogen was determined by using micro-kjeldehl method as described by Pregl (1945). Phosphorus was estimated according to Evenhuis and Dewaored (1980). Potassium was determined photometrically as described by Brown and Lilleland (1946). Fe, $\mathrm{Zn}$ and Mn were determined by Perking-Elmer Atomic Absorption Spectrophotometer model 2380, according to Johnston and Ulrich (1959). The concentration of $\mathrm{Fe}, \mathrm{Zn}$ and $\mathrm{Mn}$ were expressed as part per million (ppm) on dry weight basis.

\section{Statistical analysis:}

All data obtained in both seasons of study were subjected to analysis of variance as factorial experiments in a complete randomize blocks design. L.S.D. method was used to differentiate between means according to Snedecor and Cochran (1980).

\section{RESULTS AND DISCUSSION}

Effect of some amino acids and micronutrients treatments on growth, yield, fruit quality and chemical compositions of Canino apricot trees

\section{1- Vegetative growth aspects}

Data in Table (2) showed that the different amino acids had significantly affected the tested vegetative growth parameters of Canino apricot trees i.e. shoot length, leaves number/ shoot and leaf area, especially using the high rate $(3 \mathrm{ml} / \mathrm{L})$ combined with the other rates in the two seasons. Data concerning the effect of micronutrients on vegetative growth parameters obviously revealed that increasing micronutrients levels from 0.0 to $150 \mathrm{ppm}$ caused a gradual increment in these parameters, with little significant differences in most cases in the two seasons. The interaction effect between amino acids and micronutrients on vegetative growth parameters showed that the longest shoots, highest number of leaves/ shoot and the largest leaf area were 
obtained from the combination of amino acids at the high rate $(3 \mathrm{ml} / \mathrm{L})$, particularly those sprayed with micronutrients at the high level $(150 \mathrm{ppm})$ in the two seasons. Irrespective untreated Canino apricot trees "control", the lowest values of these parameters were registered by those sprayed with the low level of micronutrients ( $50 \mathrm{ppm}$ ) and received no amino acids treatment in the two seasons. The other treatments came in between the abovementioned treatments in the two seasons.

The obtained results may be due to the role of amino acids as they are considered as precursors and the build blocks of protein synthesis, which could be enzymes important for metabolic activities to promote cell growth (Aberg, 1961). Also, Davies (1982) indicated that amino acids contained both acid and basic groups and act as buffers, that help to maintain favorable $\mathrm{pH}$ value within the plant cell. Amino acids can impact directly or indirectly the physiological activities in plant growth and development. Promoting effect of amino acids on protecting plant cells from oxidation and all stresses as well as enhancing the biosynthesis of proteins, plant pigments, natural hormones such as IAA, gibberellin and cytokinines and cell division is reflected on stimulating vegetative growth, chemical composition and productivity (Davies, 1982; Yagodin, 1990 and Rai, 2002).

The obtained results regarding the positive effect of foliar sprays with amino acid on some vegetative growth parameters of Canino apricot trees are in agreement with those of Hanafy et al., (2012) on Valencia orange and Khattab et al., (2012) on Manfalouty pomegranate.

Moreover, enhancing vegetative growth aspects in response to micronutrients may be due to their positive effect on increasing cell division in the meristematic tissues and accelerating carbohydrates and proteins formation (Ghanta and Metra, 1993). Additionally, Nijjar (1985) indicated that these elements play an important role in the multi-biological processes such as the role of $\mathrm{Zn}$ in the synthesis of trptophan, a precursor of indole acetic acid (IAA), as well as zinc deficiency causes a reduction in RNA synthesis and ribosome stability.

The uses of micronutrients by many researchers have shown enhanced vegetative growth of different fruit species (Wassel et al., 2007; Maklad 2010 and Seyam, 2012 and Razzaq et al., 2013). They reported that Fe, $\mathrm{Zn}$ and $\mathrm{Mn}$ lonely or in combinations as foliar application enhanced vegetative growth parameters of different fruit trees.

Table 2. Effect of spraying some amino acids and micronutrients treatments on some vegetative growth aspects of Canino apricot trees during 2016 and 2017 seasons.

\begin{tabular}{|c|c|c|c|c|c|c|c|c|c|c|c|}
\hline & & \multicolumn{5}{|c|}{ First season } & \multicolumn{5}{|c|}{ Second season } \\
\hline & & \multicolumn{4}{|c|}{ Micronutrients } & \multicolumn{6}{|c|}{ Micronutrients } \\
\hline & & $0.0 \mathrm{ppm}$ & $50 \mathrm{ppm}$ & $100 \mathrm{ppm}$ & 150 ppm & Mean* & $0.0 \mathrm{ppm}$ & 50 ppm & $100 \mathrm{ppm}$ & 150 ppm & Mean* \\
\hline \multicolumn{2}{|l|}{ Amino acids } & \multicolumn{10}{|c|}{ Shoot length $(\mathrm{cm})$} \\
\hline $0.0 \mathrm{ml} / \mathrm{L}$ & & 39.6 & 41.2 & 42.6 & 43.1 & 41.63 & 42.3 & 42.9 & 43.7 & 43.9 & 43.2 \\
\hline $1 \mathrm{ml} / \mathrm{L}$ & & 43.7 & 44.3 & 45.1 & 45.8 & 44.72 & 45.2 & 45.8 & 46.7 & 46.9 & 46.15 \\
\hline $2 \mathrm{ml} / \mathrm{L}$ & & 46.7 & 47.5 & 48.0 & 48.2 & 47.60 & 48.6 & 49.2 & 49.8 & 50.2 & 49.45 \\
\hline $3 \mathrm{ml} / \mathrm{L}$ & & 48.7 & 49.1 & 49.6 & 49.8 & 49.30 & 51.1 & 51.5 & 52.1 & 52.4 & 51.78 \\
\hline Mean** & & 44.67 & 45.53 & 46.33 & 46.72 & & 46.8 & 47.35 & 48.08 & 48.35 & \\
\hline \multirow{3}{*}{ L.S.D at 0.05 for } & Micronutrients & \multicolumn{5}{|c|}{1.319} & \multicolumn{5}{|c|}{1.968} \\
\hline & Amino acids & \multicolumn{5}{|c|}{1.319} & \multicolumn{5}{|c|}{1.968} \\
\hline & Interaction & \multicolumn{4}{|c|}{2.639} & & \multicolumn{5}{|c|}{3.937} \\
\hline \multicolumn{2}{|l|}{ Amino acids } & \multicolumn{10}{|c|}{ Leaves number/shoot } \\
\hline $0.0 \mathrm{ml} / \mathrm{L}$ & & 34.5 & 34.9 & 35.6 & 35.8 & 45.2 & 36.9 & 37.4 & 37.9 & 38.2 & 37.6 \\
\hline $1 \mathrm{ml} / \mathrm{L}$ & & 36.7 & 37.1 & 37.8 & 38.0 & 37.4 & 39.3 & 39.9 & 41.8 & 42.0 & 40.8 \\
\hline $2 \mathrm{ml} / \mathrm{L}$ & & 39.8 & 41.3 & 41.9 & 42.3 & 41.3 & 43.7 & 43.8 & 44.6 & 45.1 & 44.3 \\
\hline $3 \mathrm{ml} / \mathrm{L}$ & & 43.6 & 45.2 & 48.1 & 46.8 & 45.4 & 46.2 & 43.8 & 47.2 & 47.8 & 46.3 \\
\hline Mean** & & 38.7 & 39.6 & 40.4 & 40.7 & & 41.5 & 41.2 & 42.9 & 43.3 & \\
\hline \multirow{3}{*}{ L.S.D at 0.05 for } & Micronutrients & \multicolumn{5}{|c|}{1.346} & \multicolumn{5}{|c|}{1.611} \\
\hline & Amino acids & \multicolumn{5}{|c|}{1.346} & \multicolumn{5}{|c|}{1.611} \\
\hline & Interaction & \multicolumn{4}{|c|}{3.693} & & \multicolumn{5}{|c|}{3.223} \\
\hline \multicolumn{2}{|l|}{ Amino acids } & \multicolumn{10}{|c|}{ Leaf area $\left(\mathrm{cm}^{2}\right)$} \\
\hline $0.0 \mathrm{ml} / \mathrm{L}$ & & 31.7 & 31.9 & 32.4 & 32.4 & 32.1 & 31.4 & 31.8 & 32.6 & 32.9 & 32.2 \\
\hline $1 \mathrm{ml} / \mathrm{L}$ & & 33.2 & 33.1 & 33.9 & 34.2 & 33.6 & 33.8 & 34.1 & 34.6 & 34.8 & 34.3 \\
\hline $2 \mathrm{ml} / \mathrm{L}$ & & 35.8 & 36.3 & 37.1 & 37.5 & 36.7 & 36.2 & 36.5 & 36.9 & 37.1 & 36.7 \\
\hline $3 \mathrm{ml} / \mathrm{L}$ & & 37.6 & 38.2 & 38.5 & 38.9 & 38.3 & 38.4 & 38.5 & 38.7 & 38.9 & 38.6 \\
\hline Mean** & & 34.6 & 34.9 & 35.5 & 35.8 & & 44.0 & 35.2 & 35.7 & 35.9 & \\
\hline \multirow{3}{*}{ L.S.D at 0.05 for } & Micronutrients & \multicolumn{5}{|c|}{1.395} & \multicolumn{5}{|c|}{1.169} \\
\hline & Amino acids & \multicolumn{5}{|c|}{1.395} & & & 1.169 & & \\
\hline & Interaction & & & 2.790 & & & & & 2.337 & & \\
\hline
\end{tabular}

\section{2- Fruiting aspects}

Data in Table (3) indicated that all used amino acids and micronutrients as well as their combinations had a pronounced effect on increasing fruit set of Canino apricot trees in the two seasons. However, the highest fruit set \% was scored by the interaction of amino acids at the high rate, especially those received micronutrients foliar spray at the high level in the two seasons. Regardless control trees, the lowest fruit set $\%$ was gained by those sprayed with amino acids at the low rate $(1 \mathrm{ml} / \mathrm{L})$ and received no micronutrients treatment in the two seasons. Furthermore, all tested amino acids and micronutrients treatments as well as their combinations increased fruit yield/ fed. in both seasons. However, the highest rate of amino acids $(3 \mathrm{ml} / \mathrm{L})$ or the highest level of micronutrients $(150 \mathrm{ppm})$ recorded the highest fruit yield/ fed. as compared with the other concentrations in the two seasons. In general, the highest yield/ fed. was detected by the combined treatment between amino acids at $3 \mathrm{ml} / \mathrm{L}$ and micronutrients at $150 \mathrm{ppm}$ in the two seasons of this study. Irrespective un-treated trees, the lowest yield/ fed. was gained by those received the combined treatment between the lowest level of amino acids and sprayed with distilled water in the two seasons. The 
remained treatments came in between the abovementioned treatments in the two seasons.

In general, the positive effects of amino acid foliar spray applications could be attributed to improve pollen tube ovule penetration and delay ovule senescence, which enhance fruit set and yield of Golden Delicious and Granny Smith apples (Arabloo et al., 2017). Foliar sprays of amino acids that gave positive effects on tree fruiting parameters of Canino apricot trees are in harmony with those findings of Fayek et al., (2011) pear, Khattab et al., (2012) pomegranate, Belal et al., (2016) on grapevine, Khattab et al., (2016) on mango, Ilie et al., (2017) on apple and Ahmed et al., (2017) on orange. They mentioned that foliar application of amino acids increased the fruit set and fruit yield. The obtained results concerning the positive effect of micronutrients mixture ( $\mathrm{Fe}, \mathrm{Zn}$ and $\mathrm{Mn}$ ) in this regard are in agreement with those reported by El-Seginy et al., (2003) on apple , El-Kosary et al., (2011) on mango, El-Sheikh et al., (2007) and Yadav et al., (2013) on peach, Tariq et al., (2007) and Kazi et al., (2012) on orange, Khorsandi et al., (2009) on pomegranate, Hassan et al., (2010) on plum , Seyam (2012) on mandarin, Razzaq et al., (2013), Nirmaljit et al., (2015) and Ilyas et al., (2015) on Kinnow mandarin, Saadati et al., (2016) on olive and Suman et al., (2016) and Zagade et al., (2017) on guava. They indicated that foliar application of micronutrients such as, Fe, $\mathrm{Zn}$ and $\mathrm{Mn}$ alone or in combinations enhanced fruiting parameters of the different fruit trees.

Table 3. Effect of spraying some amino acids and micronutrients treatments on fruit set and fruit yield/fed. of Canino apricot trees during 2016 and 2017 seasons.

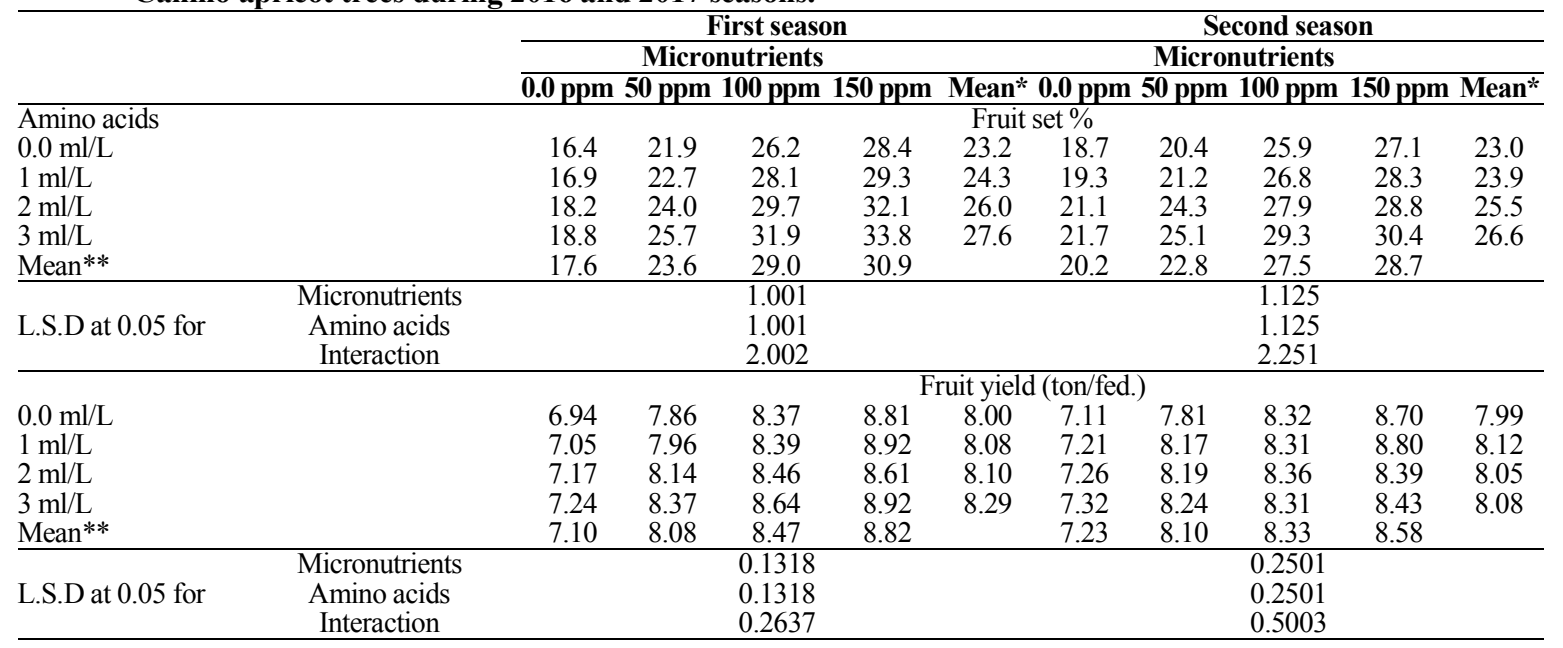

\section{3- Fruit physical parameters}

It was interest to notice that there was a positive relationship between the values of fruit weight and fruit firmness and amino acids or micronutrients treatments. Hence, as the rates of amino acids or micronutrients increased the values of fruit weight and fruit firmness increased up to the maximum increasing at the high rates of amino acids or micronutrients in the two seasons (Table, 4).

In general, the highest values of fruit weight and fruit firmness were recorded by using the combination of micronutrients at the high level, particularly those received amino acids at the high rate $(3 \mathrm{ml} / \mathrm{L})$ in both seasons. Regardless control trees, the lowest fruit weight and fruit firmness were gained by those sprayed with the low level of micronutrients and received no amino acids in the two seasons.

\section{4- Fruit chemical parameters}

It was found that the values of fruit chemical quality i.e. T.S.S. \%, total sugars $\%$ and V.C (mg/ $100 \mathrm{ml}$ juice) are proportionally increased with increment of amino acids or micronutrients levels in the two seasons (Tables, 5 and 6).

Therefore, the high level of amino acids or micronutrients scored the highest values in this respect as compared with untreated trees in the two seasons. In general, all resulted combinations between amino acids and micronutrients increased the values of these parameters with significant differences in most cases when compared with control trees (untreated) in the two seasons. However, 3 $\mathrm{ml} / \mathrm{L}$ amino acids-sprayed trees joined with micronutrients at $150 \mathrm{ppm}$ induced the highest values in this concern in both seasons.

Furthermore, all studied rates of amino acids and micronutrients as well as their interactions decreased total acidity $\%$, but it failed to induce a significant difference between them in the two seasons.

The obtained results concerning the positive effect of amino acids on enhancing fruit physical and chemical properties of Canino apricot trees go in line with earlier studies of Fayek et al., (2011) on pear, Khattab et al., (2012) on pomegranate, Hanafy et al., (2012) and El-Shazly and Mustafa (2013) on orange, Belal et al., (2016) on grapevines and Arabloo et al., (2017) on apples. They revealed that sprayed amino acids improved fruit juice $\%$, total soluble solids (TSS), total sugars and V.C. contents as compared with control. The recorded results of micronutrients mixture ( $\mathrm{Fe}, \mathrm{Zn}$ and $\mathrm{Mn}$ ) dealing with their prospective affect on enhancing physical and chemical properties of Canino apricot fruits are in harmony with earlier studies of ElSeginy et al., (2003) on apple, Tariq et al., (2007) on orange, Wassel et al., (2007) on grapevines, El-Sheikh et al., (2007) on peach, Khorsandi et al., (2009) on pomegranate, Hassan et al., (2010) on plum, Anees et al., (2011) and El-Kosary et al., (2011) on mango, Kazi et al., (2012) on orange, Razzaq et al., (2013) and Nirmaljit et al., (2015) on Kinnow mandarin, Ali et al., (2014) on peach, Saadati et al., (2016) on olive and Zagade et al., (2017) on guava. 
Table 4. Effect of spraying some amino acids and micronutrients treatments on fruit weight and fruit firmness of Canino apricot trees during 2016 and 2017 seasons.

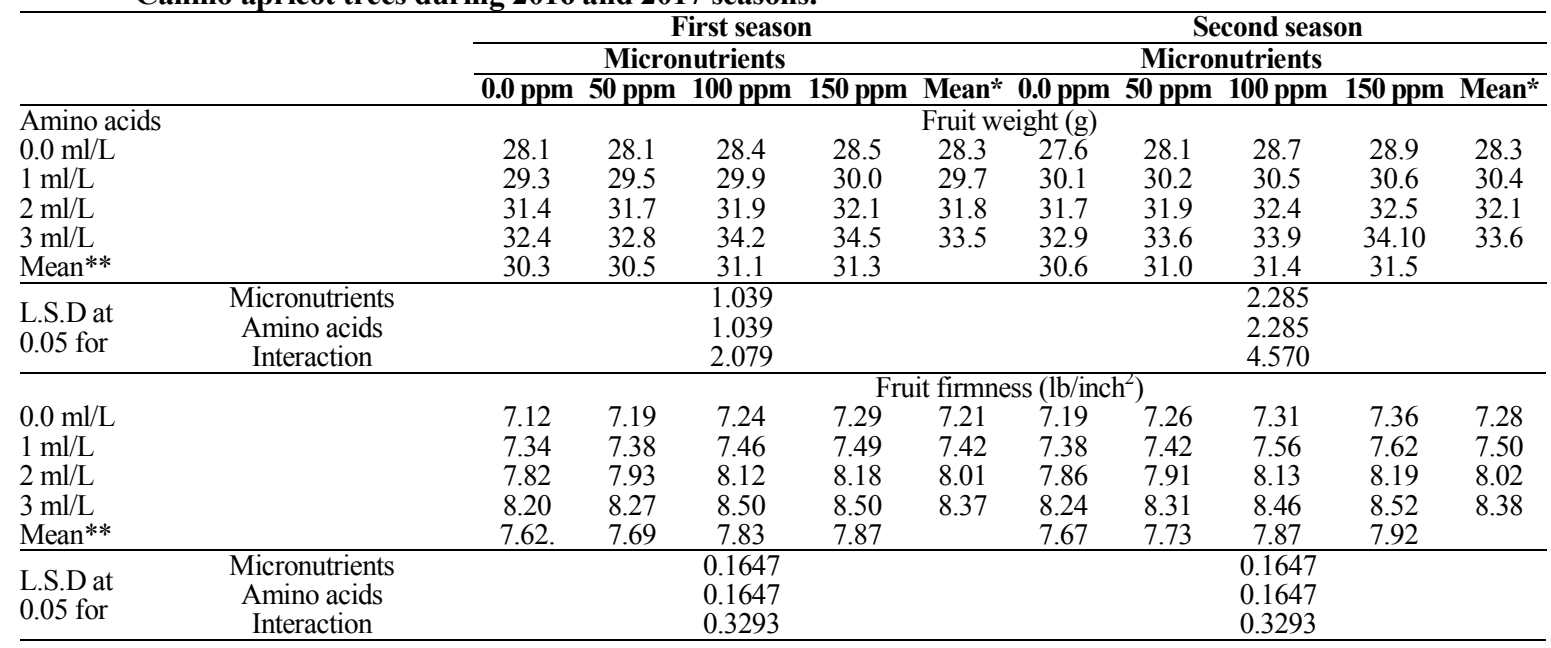

Table 5. Effect of spraying some amino acids and micronutrients treatments on fruit T.S.S \% and fruit total sugars $\%$ of Canino apricot trees during 2016 and 2017 seasons.

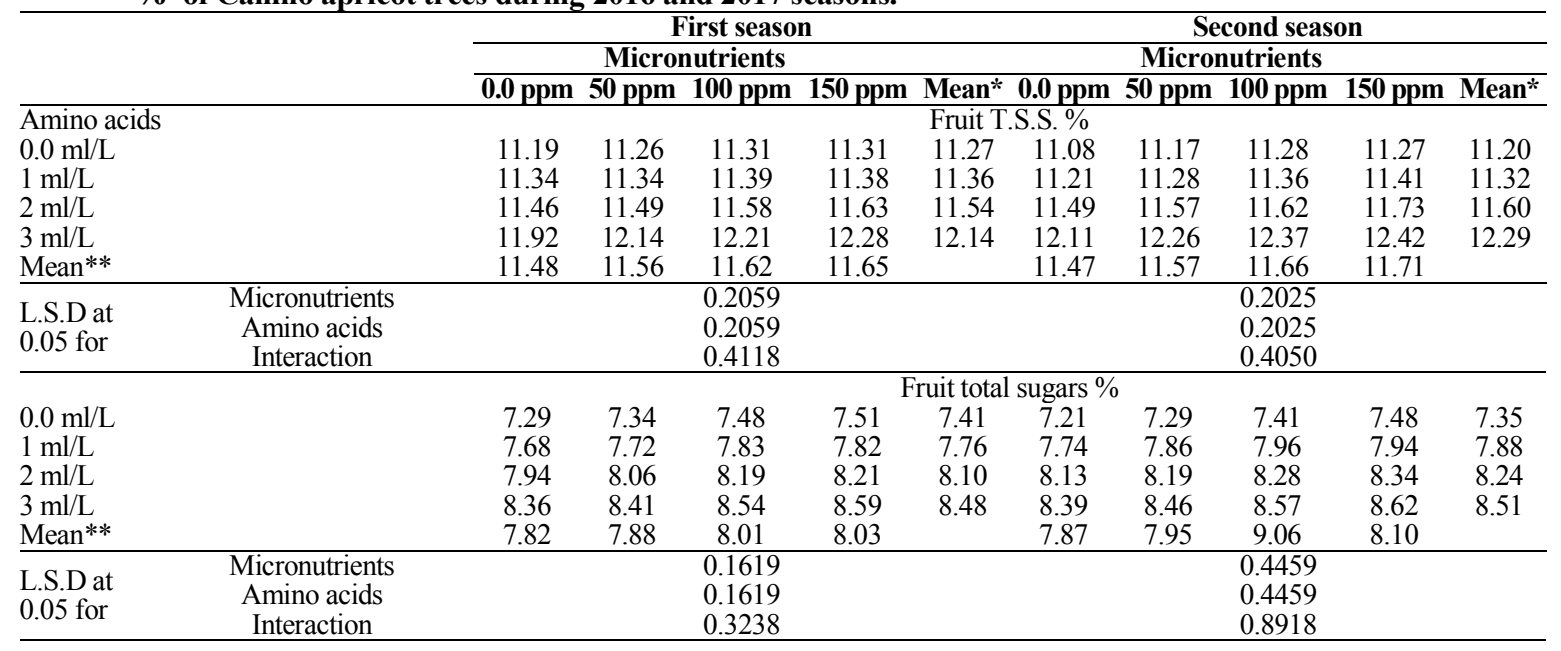

Table 6. Effect of spraying some amino acids and micronutrients treatments on fruit total acidity and fruit V.C of Canino apricot trees during 2016 and 2017 seasons.

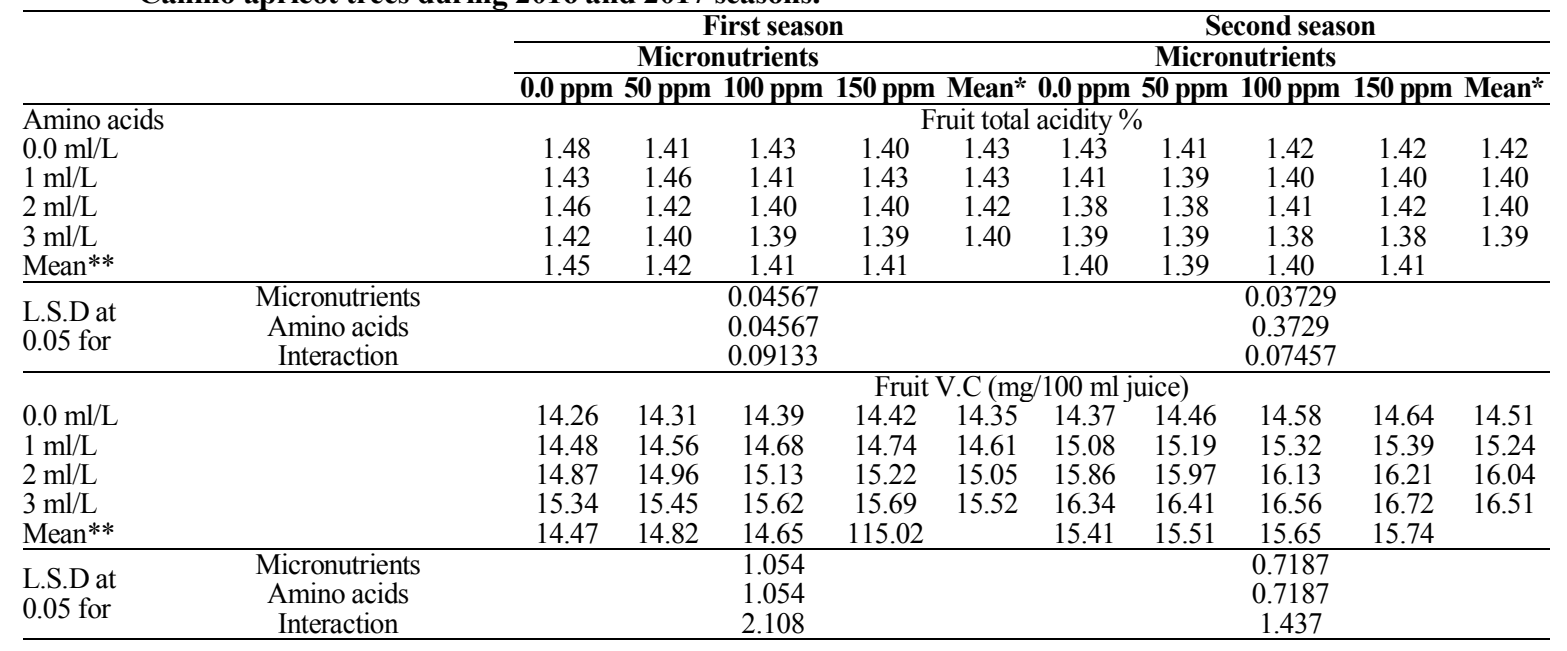

\section{4- Leaf mineral content}

Leaf mineral content determinations in Tables (7 and 8) revealed that the values of leaf $\mathrm{N}, \mathrm{P}, \mathrm{K}, \mathrm{Fe}, \mathrm{Zn}$ and Mn contents are linearly increased with increasing the rates of amino acids or micronutrients, hence the high rate of amino acids ( $3 \mathrm{ml} / \mathrm{L})$ or micronutrients $(150 \mathrm{ppm})$ showed to be the most effective ones for inducing the highest values in this respect in both seasons. Regarding the 
interaction effect between amino acids and micronutrients, data in Tables ( 7 and 8 ) indicate that all resulted combinations succeeded in increasing the values of these parameters, with superior for the combination of amino acids at the high rate with significant differences in most cases during the two seasons of study. However, the highest values of leaf $\mathrm{N}, \mathrm{P}, \mathrm{K}, \mathrm{Fe}, \mathrm{Zn}$ and $\mathrm{Mn}$ contents were obtained by using the doubled treatment between amino acids at $3 \mathrm{ml} / \mathrm{L}$ and micronutrients at $150 \mathrm{ppm}$ in the two seasons.

Table 7. Effect of spraying some amino acids and micronutrients treatments on leaf $N$, $P$ and $K$ percentages of Canino apricot trees during 2016 and 2017 seasons.

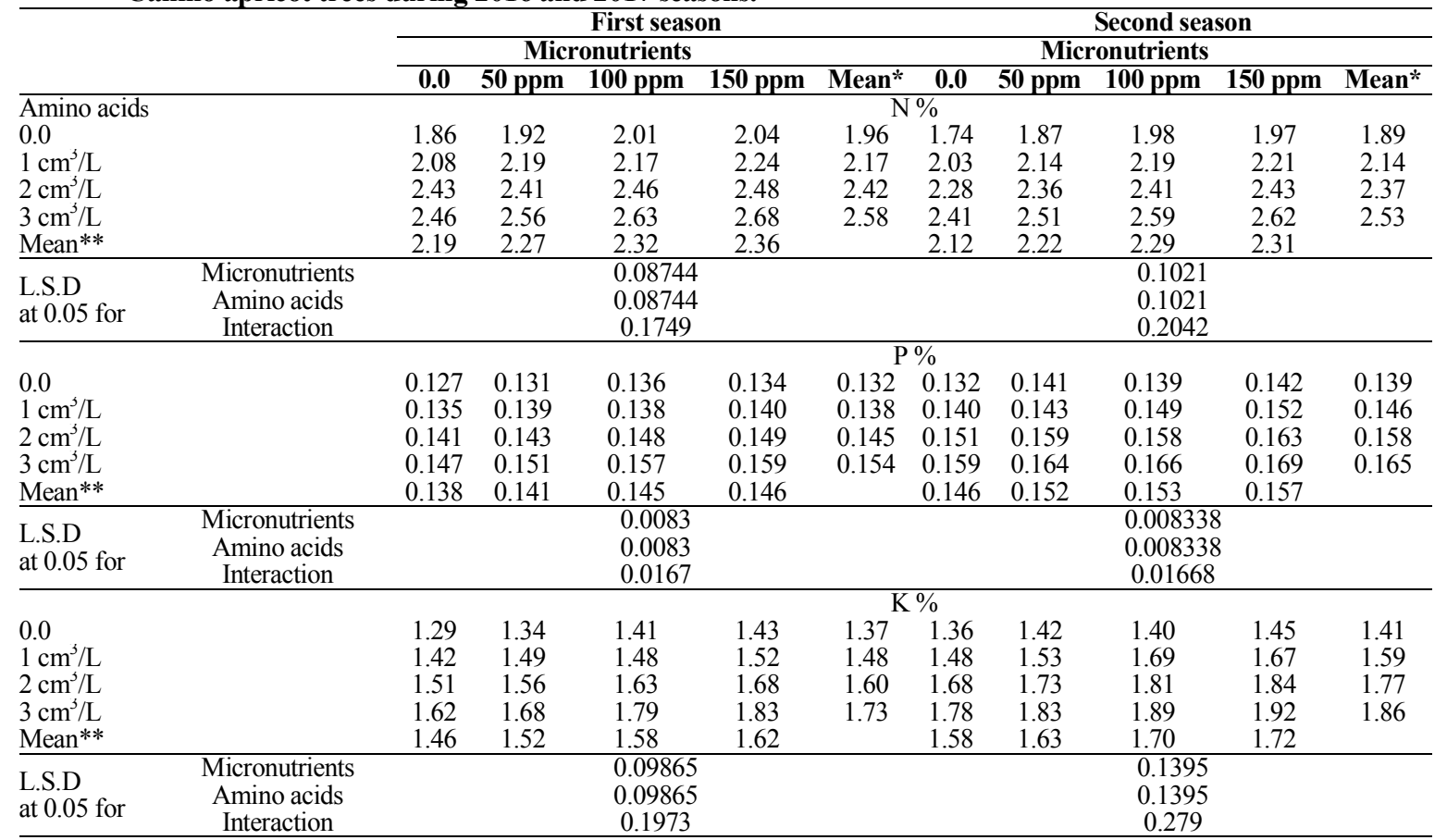

Table 8. Effect of spraying some amino acids and micronutrients treatments on leaf $\mathrm{Fe}, \mathrm{Zn}$ and Mn contents of Canino apricot trees during 2016 and 2017 seasons.

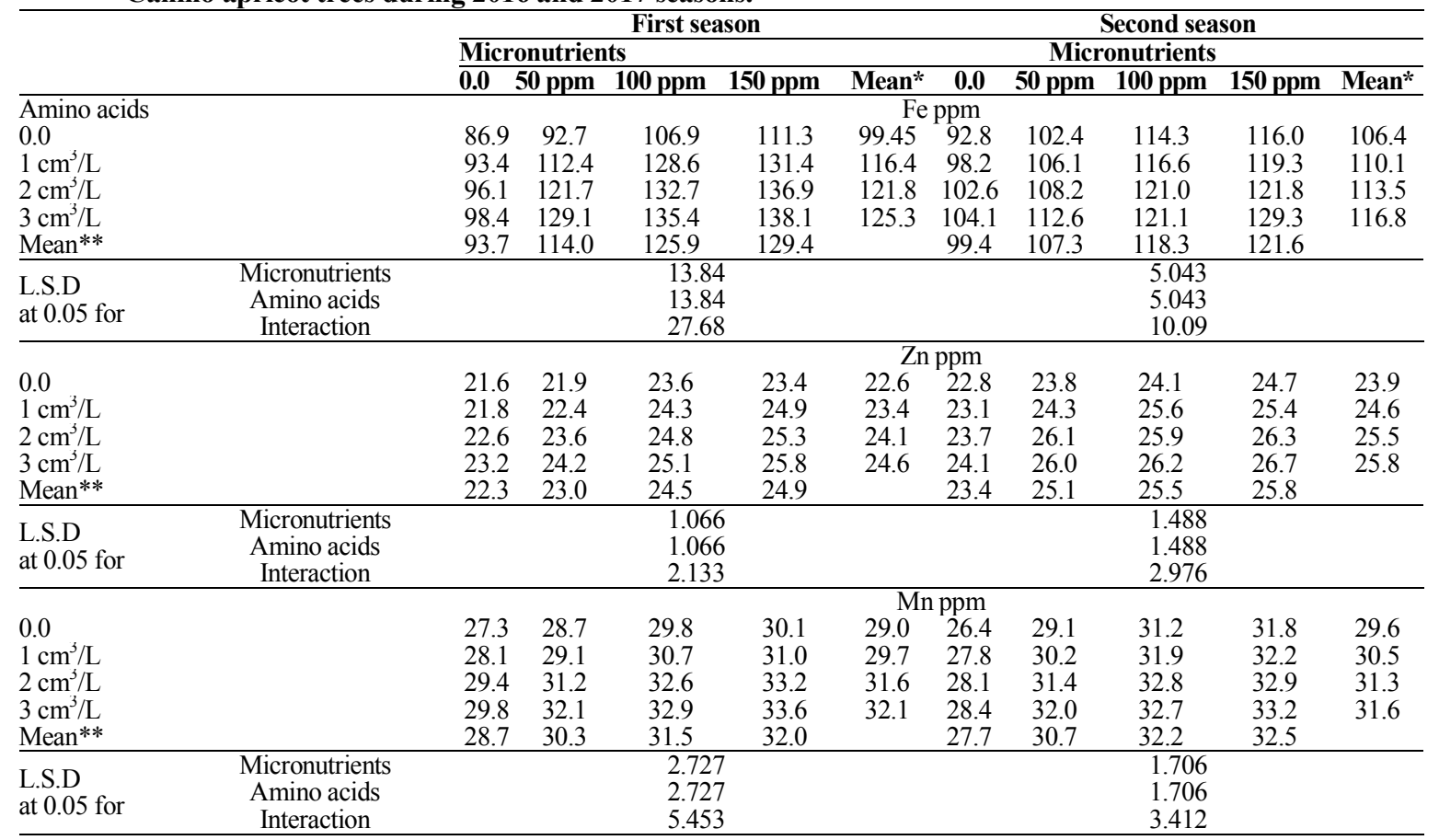

The obtained results of amino acids in terms of leaf mineral content of Canino apricot trees go in line with earlier studies of Fayek et al., (2011) on pear. They reported that amino acid treatments improved the nutritional status of the trees. Also, El-Shazly and Mustafa (2013) on Washington Navel orange revealed that foliar sprays with amino acids improved leaf chlorophyll content and leaf mineral contents (N, P, K, Ca and Mg). 
The obtained results of micronutrients mixture $(\mathrm{Fe}$, $\mathrm{Zn}$ and $\mathrm{Mn}$ ) on leaf mineral content of Canino apricot trees are in accordance with those reported by El-Seginy et al., (2003) on apple, El-Sheikh et al., (2007) on peach, Hassan et al., (2010) on plum, Abd-Elmegeed et al., (2013) on pear and Tariq et al., (2007) on orange and Razzaq et al., (2013) and Nirmaljitet al., (2015) on Kinnow mandarin. They mentioned that foliar sprays with some micronutrients alone or in combinations improved leaf chemical constituents in most cases.

Conclusively, in order to produce good quality Canino apricot fruits with more yield, it is preferable to spray the trees with amino acids at $3 \mathrm{ml} / \mathrm{L}$ supplemented with micronutrients at $150 \mathrm{ppm}$ foliar spray three times a year.

\section{REFERENCES}

A.O.A.C "Association of Official Agricultural Chemists" (1995). Official Methods of Analysis pub. chapter (37): 1-32 and chapter (45): 16-19. Inter. Suite 4002200 Wilson Boulevard Arlingtion, Virginia 22201-3301. USA.

Abd-Elmegeed, Nagwa A., A. Wesam Nabeel and M. Nasr Magda (2013). Effect of foliar application of some nutrients on "Le-Conte" pear trees grown under calcareous soil conditions. Egypt. J. Hort., 40 (2): 277293.

Aberg, B. (1961). Nucleic acids and proteins in plants. Encycl. Plant Physiol., (14) Spriger Verlag, Berlin.

Ahmed, Fatma K.; A . Hamed Nadia; M. A. Ibrahim and A. M. ELazazy (2017). Effect of tryptophan and some nutrient elements foliar application on yield and fruit quality of Washington Navel orange. J. Hort. Sci. \& Ornamental Plants, 9 (2): 86-97.

Ali, A.; S. Perveen; S.N.M. Shah; Z. Zhang; F. Wahid; M. Shah; S. Bibi and A. Majid (2014). Effect of foliar application of micronutrients on fruit quality of peach. Amer. J. Plant Sci., 5: 1258-1264.

Anees, M.; F.M. Tahir; J. Shahzad and N. Mahmood (2011). Effect of foliar application of micronutrients on the quality of mango (Mangifera indica L.) cv. Dusehri fruit. Mycopath (2011) 9(1): 25-28.

Arabloo, M.; M. Taheri; H. Yazdani and M. Shahmoradi (2017). Effect of foliar application of amino acid and calcium chelate on some quality and quantity of Golden Delicious and Granny Smith apples. Trakia J.1 Sci., 15 (1):14-19.

Belal, B.E.A.; M.A. El-Kenawy and M.K. Uwakiem (2016). Foliar application of some amino acids and vitamins to improve growth, physical and chemical properties of Flame Seedless grapevines. Egypt. J. Hort. 43, (1): 123136.

Brown, J.D. and O. Lilleland (1946). Rapid determination of potassium and sodium in plant material and soil extract by flame photometry. Proc. Amer. Hort. Sci., 48: 341346.

Caliskan, O.; S. Bayazit and A. Sumbul (2012). Fruit quality and phytochemical attributes of some apricot (Prunus armeniaca L.) cultivars as affected by genotypes and seasons. Notulae Botanicae Horti. Agrobotanici ClujNapoca 40(2): 284-294.

Das, D.K. (2003). Micronutrients: Their behaviors in soils and plants. Kalyani publ., Ludhiana: 1-2.

Davies, D.D. (1982). Physiological aspects of protein turn over. Encycl. Plant Physiol., 45: 481- 487.
Drogoudi, P.D.; S. Vemmos; G. Pantedelis; E. Petri; C. Tzoutzoukou; and I. Karayannis (2008). Physical characters and antioxidant, sugar, and mineral nutrient contents in fruit from 29 apricot (Prunus armeniaca L.) cultivars and hybrids. Journal of Agricultural and Food Chemistry 56: 10754-10760.

El-Kosary, S.; I.E. El-Shenawy and S.I. Radwan (2011). Effect of microelements, amino and humic acid on growth, flowering and fruiting of some mango cultivars. J. Hort. Sci. \& Ornamental Plants, 3(2): 152-161.

El-Seginy, Amal M.; S.M.N. Malaka; W.M. Abd El-Messeih, and G.I. Eliwa (2003). Effect of foliar spray of some micronutrients and Gibberellins on leaf mineral content, fruit set, yield and fruit quality of "Anna" apple trees. Alex. J. Agric. Res., 48 (3), 137- 143.

El-Shazly, S.M. and N.S. Mustafa (2013). Enhancement yield, fruit quality and nutritional status of Washington Navel orange trees by application of biostimulants. Journal of Applied Sciences Research, 9(8): 5030-5034.

El-Sheikh, M.H.; S.A.A. Khafgy and S.S. Zaied (2007). Effect of foliar application with some micronutrients on leaf mineral content, yield and fruit quality of "Florida Prince Desert Red" peach trees. J. Agri. and Bio. Sci., 3, 309-315.

Evenhuis, V. and P.W. Dewaored (1980). Principles and practices in plant analysis. FAO Soils Bull. 38(1): 152163.

Fayek, M.A.; T.A. Yehia; E.M.M El. Fakhrany and A.M. Farag (2011). Effect of ringing and amino acids application on improving fruiting of "Le Conte" pear trees. J. Hort. Sci. \& Ornamental Plants, 3(1): 01-10.

Fratianni, F.; M.N. Ombra; A. Acierno; L. Cipriano and F. Nazzaro (2018). Apricots: biochemistry and functional properties. Current Opinion in Food Science 19:23-29.

Ghanta, P.K. and S.K. Metra (1993). Effect of micronutrients on growth, flowering, leaf nutrient content and yield of banana cv., Giant cavandishii. Crop Research, 2: 284287.

Hanafy, A. A.H.; M.K. Khalil; A.M. Abd EI- Rahman and A.M. Hamed Nadia (2012). Effect of zinc, tryptophan and indole acetic acid on growth, yield and chemical composition of Valencia orange trees. Journal of Applied Sciences Research, 8(2): 901-914.

Hassan, H.S.A.; S.M.A. Sarrwy and E.A.M. Mostafa (2010). Effect of foliar spraying with liquid organic fertilizer, some micronutrients and gibberellins on leaf minerals content, fruit set, yield, and fruit quality of "Hollywood" plum trees. Agriculture and Biology Journal of North America, 1, 638-643.

Ilie, A. V.; P. Cristina and D. Hoza (2017). Influence of foliar application of amino acids on yield and quality attributes of apple. Journal of Horticulture, Forestry and Biotechnology, 21(3), 104- 107.

Ilyas, A.; A.M. Yasin; H. Mumtaz; A. Muhammad; A. Rashid and K. Ali (2015). Effect of micronutrients ( $\mathrm{Zn}, \mathrm{Cu}$ and B) on photosynthetic and fruit yield attributes of Citrus reticulata Blanco var. kinnow. Pak. J. Bot., 47(4): 12411247.

Iordanescu, O.A.; E. Alexa; R. Micu; and M.A. Poiana (2012). Bioactive compounds and antioxidant properties of apples cultivars from Romania in different maturity stage. Journal of Food Agriculture and Environment 10(1):147-151.

Johnston, C.M. and A. Ulrich (1959). Analytical methods for use plant analysis. Coll. of Agric., Exp. State Bull.; 766.

Kazi, S.S.; S. Ismail and K.G. Joshi (2012). Effect of multimicronutrient on yield and quality attributes of sweet orange. African J. Agric. Res., 7(29):4118-23. 
Khan, A.S.; B. Ahmad; M.J. Jaskani; R. Ahmad and A.U. Malik (2012). Foliar application of mixture of amino acids and seaweed (Ascophylum nodosum) extract to improve growth and physicochemical properties of grapes. Int J. Agri. \& Biol., 14(3):383-388.

Khattab, M.M; A.E.A. Shaban and E. H. Alhassan (2016). Impact of foliar application of calcium, boron and amino acids on fruit set and yield of Ewais and Fagry Kelan Mango cultivars. J. Hort. Sci. \& Ornamental. Plants, 8 (2): 119-124.

Khattab, M. M.; A.E.A. Shaban; A.H. El-Shrief and A.S.E. Mohamed (2012). Effect of humic acid and amino acids on pomegranate trees under deficit irrigation. I: Growth, flowering and fruiting. J. Hort. Sci. \& Ornamental Plants, 4 (3): 253-259.

Khorsandi, F.; F. AlaeiYazdi and M.R. Vazifehshenas (2009). Foliar zinc fertilization improves marketable fruit yield and quality attributes of pomegranate. Int. J. Agri. Biol., 11 (6), 766-770.

Khurshid, F.; R.A. Khattak and S. Sarwar (2008). Effect of foliar applied ( $\mathrm{Zn}, \mathrm{Fe}, \mathrm{Cu} \& \mathrm{Mn}$ ) in citrus production. Science Technology \& Development, 27(1\&2): 34-42.

Leccese, A.; S. Bureau; M. Reich; C. Renard; J.C. Audergon and C. Mennone al. 2010. Pomological and nutraceutical properties in apricot fruit: Cultivation systems and cold storage fruit management. Plant Foods Human Nutrition 65: 112-120.

Maklad, T.N.A. (2010). A comparative study on effect of source, rate and application method of some fertilizers on growth and yield of banana plant. Ph. D. Dissertation. Fac. Agric. Benha University. Egypt.

Malik, C.P. and M.B. Singh (1980). Plant Enzymology and Histo-Enzymology. A Text Manual: 276-277. Kalyani Publishers, New Delhi, India.

Mengel, K. and E.A. Kirby (1987). Principles of Plant Nutrition. International Potash Institute, Berns, Switzer-land. pp 453-461.

Nijjar, G.S. (1985). Nutrition of Fruit Trees. Kalyani Publishers New Delhi, pp: 50-100, India.

Nirmaljit, K.; P.K. Monga; P.K. Arora and K. Kumar (2015). Effect of micronutrients on leaf composition, fruit quality and yield of Kinnow mandarin. J. Appl. \& Nat. Sci. 7 (2): $639-643$.

Pregl, E. (1945). Quantitative Organic Micro Analysis 4th Ed. Chundril, London.

Rai, V.K. (2002). Role of amino acids in plant responses to stress, Biol. Plant, 45: 471-478.
Razzaq, K.; A.S. Khan; A.U. Malik; M. Shahid and S. Ullah (2013). Foliar application of Zinc influences the leaf mineral status, vegetative and reproductive growth, yield and fruit quality of Kinnow mandarin. J. Plant Nutrition 36: 1479-1495.

Saadati, S.; N. Moallemi; S.M.H. Mortazavi and S.M. Seyyednejad (2016). Foliar applications of zinc and boron on fruit set and some fruit quality of olive. Vegetos 29 (2):1-5.

Seyam, G.A.A. (2012). Respones of Balady mandarin trees to some horticultural treatments. Ph.D. Thesis Fac. of Agric., Benha Univ., Egypt.

Snedecor, W. and W.G. Cochran (1980). Statistical Methods, 7th ed. Iowa State Univ. Press Ames. Iowa. U.S.A.

Suman, M.; S.V. Dubalgunde; O. Poobalan and D. P. Sangma (2016). Effect of foliar application of micronutrients on yield and economics of guava (Psidium guajava L.) CV. L-49. International Journal of Agriculture, Environment and Biotechnology, 9(2): 221-224.

Swietlik, D. (2002). Zinc nutrition of fruit trees by foliar sprays. Acta Hort., 594: 123-129.

Tariq, M.; M. Sharif; Z. Shah and R. Khan (2007). Effect of foliar application of micronutrients on the yield and quality of sweet orange (Citrus sinensis, L.). Paki. J. Bio. Sci., 10(1): 1823-1828.

Wassel, A.H.; M. Abd El-Hameed; A. Gobara and M. Attia (2007). Effect of some micronutrients, gibberllic acid and ascorbic acid on growth, yield and quality of White Banaty seedless grapevines. African Crop Science Conference Proceedings, 8: 547-553.

Yadav, V.; P.N. Singh and P. Yadav (2013). Effect of foliar fertilization of boron, zinc and iron on fruit growth and yield of low-chill peach cv. Shrbati. International Journal of Scientific and Research Publications, 3 (8): 16.

Yagodin, B.A. (1990). Agricultural Chemistry. Mir Publishers Moscow, 278- 281.

Zagade, P. M.; G.R. Munde and A.H. Shirsath (2017). Effect of foliar application of micronutrients on yield and quality of guava (Psidium guajava L.) Cv. Sardar. Journal of Pharmacy and Biological Sciences, 12 (5): 56-58.

Zia, M.H.; R. Ahmad; I. Khalig and M. Irshad (2006). Micronutrients status and management in orchards: applied aspects. Soil \& Environ. 25, 6-16.

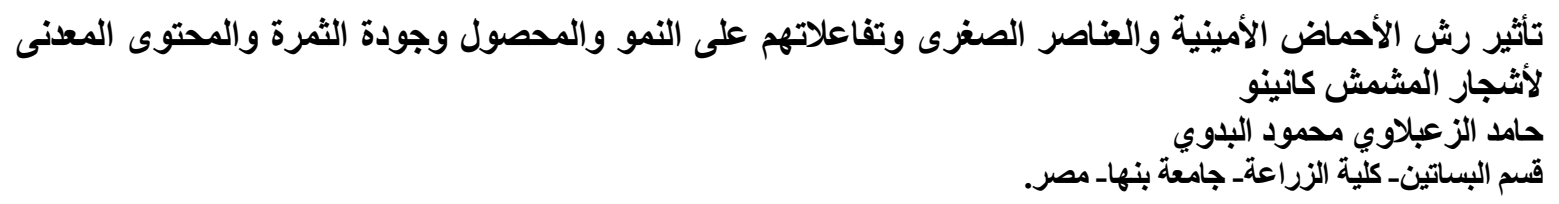

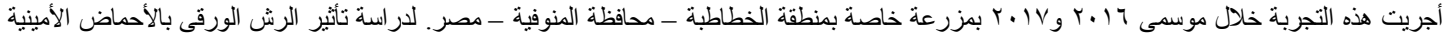

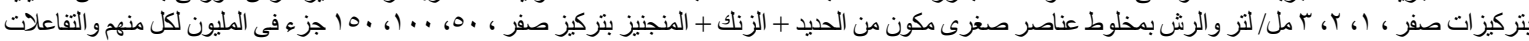

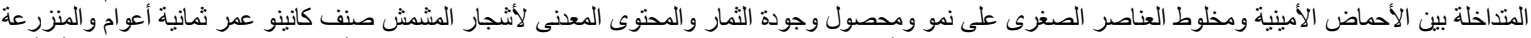

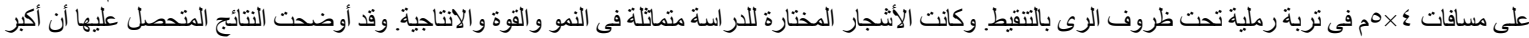

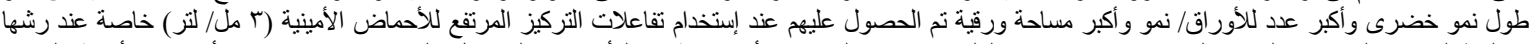

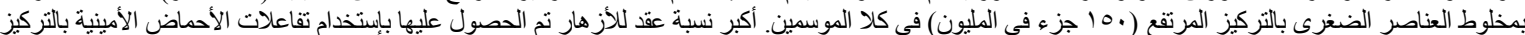

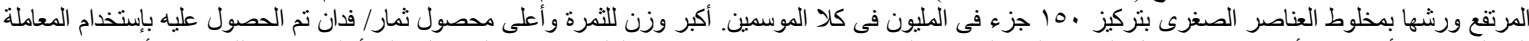

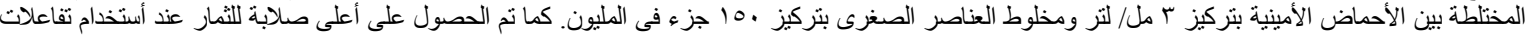

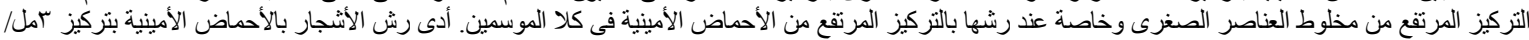

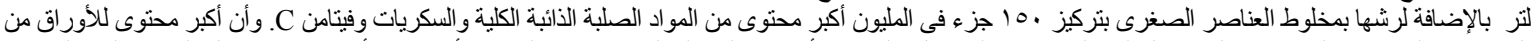

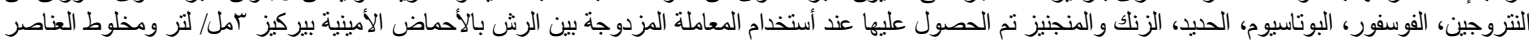

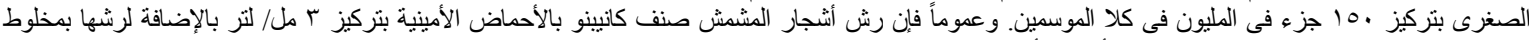

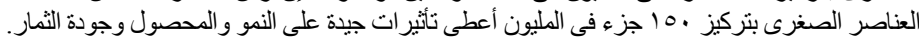

